\title{
Anatomical Study of the Digastric Muscle: Variations in the Anterior Belly
}

\author{
Estudio Anatómico del Músculo Digástrico: Variación en el Vientre Anterior
}

Bianca Maria Liquidato; Mirna Duarte Barros; Adriana Leal Alves \& Celina Siqueira Barbosa Pereira

\begin{abstract}
LIQUIDATO, B. M.; BARROS, M.D.; ALVES, A. L. \& PEREIRA, C.S. B. Anatomical study of the digastric muscle: Variations in the anterior belly. Int. J. Morphol., 25(4):797-800, 2007.

SUMMARY: The digastric muscle is formed by two muscle bellies: one anterior and one posterior, joined by an intermediate tendon. It is localized in the anterior cervical region. The anterior belly divides the region between the hyoid bone and the mandible into two: laterally the submandibular triangle, and medially the submental triangle. The anatomical variations described in the literature relate to the anterior belly and consist of differences in shape and muscle attachment. This cross-sectional cohort study had the objective of describing anatomical variations in the anterior belly of the digastric muscle. The neck regions of 10 cadavers of male adults were dissected in the Department of Morphology, between June 2004 and June 2006. The digastric muscles that presented anatomical variations were photographed using a Sony Cyber-shot DSC-T1 camera, with a Carl Zeiss Vario-Tessar lens and their bellies were measured using a universal pachymeter. Anatomical variations in the anterior bellies of the digastric muscle were observed in four individuals. Cases 1 and 4 presented a unilateral right variation, with an anomalous anterior belly. Cases 2 and 3 presented bilateral variation, with the presence of two supernumerary bellies. The anatomical variations observed on this study related only to the anterior belly, as previously described by other authors. It is important to consider the occurrence of these variations in the digastric muscle when differentiating between cervical masses and during surgical procedures on the anterior region of the neck.
\end{abstract}

KEY WORDS: Neck muscles; Anatomy; Hyoid bone.

\section{INTRODUCTION}

The digastric muscle is a suprahyoid muscle formed by two muscle bellies: one anterior and the other posterior. These are joined together by an intermediate tendon that passes through a fibrous sling that is attached to the body of the hyoid bone (Lockhart et al., 1983). There are another three suprahyoid muscles: the geniohyoid, stylohyoid and mylohyoid, which are also inserted in the hyoid bone and, together with the digastric muscle, anchor this bone against the traction of the infrahyoid muscles (Lockhart et al.).

The anterior belly of the digastric muscle originates in the digastric fossa, in the lower interior of the mandible, while the posterior belly originates in the mastoid notch, on the medial side of the mastoid process of the temporal bone. The two bellies are inserted in the body of the hyoid bone by means of a tendon. When the mandible is fixed, the digastric muscle raises the hyoid bone, and when the hyoid is fixed, the digastric muscle opens the mouth by lowering the mandible (Drake et al., 2005).
The digastric muscle is located in the anterior region of the neck and its bellies are the limits of the submandibular (digastric), submental and carotid triangles. The submandibular triangle is delimited by the anterior and posterior bellies of the digastric muscle and by the inferior margin of the mandible. It contains the submandibular gland, submandibular lymph nodes, facial vein, hypoglossal nerve, nerves and vessels for the mylohyoid muscle and the carotid sheath, which contains the external and internal carotid arteries, internal jugular vein and vagus nerve. The submental triangle is delimited by the anterior belly of the digastric muscle, the hyoid bone and the anterior median line, and contains submental lymph nodes and the anterior jugular vein. The carotid triangle is delimited by the posterior belly of the digastric muscle and the superior belly of the omohyoid muscle, and by the anterior margin of the sternocleidomastoid muscle. It contains deep cervical lymph nodes and the carotid sheath, with the common carotid artery, branches of the external carotid artery, the internal jugular vein and tributaries 
and the hypoglossal, accessory and vagus nerves (Drake $e t$ al.; Snell, 1999; Sociedade Brasileira de Anatomia, 2001).

The development of the anterior belly of the digastric muscle begins in the fourth week of pregnancy, from the first pharyngeal arch, while the poster belly originates from the second pharyngeal arch (Moore \& Persaud, 2004). Since the structures derived from each pharyngeal arch are innervated by the nerve corresponding to each arch, the anterior belly of the digastric muscle is innervated by the trigeminal nerve (fifth cranial pair), while the posterior belly is innervated by the facial nerve (seventh cranial pair) (Drake et al.).

There have been descriptions of anatomical variations in the digastric muscle ever since 1847 , as pointed out by Bergman et al. (2002). Testut (1905) reported variations in the anterior belly, with the presence of a supernumerary fascicle inserted in the raphe of the mylohyoid muscle, or in the hyoid bone or the digastric fossa of the opposite side. He emphasized that this variation was frequently unilateral and constituted a "trigastric" muscle.

Recently, Fujimura et al. (2003) proposed that the classification of anatomical variations in the anterior belly of the digastric muscle should be based on the position of the attachments of the muscle bellies. Until then, variations were described in accordance with the classifications of Zlabek (1933), which took into account their phylogenetic and ontogenetic development, and the classifications of Yamada (1935), which enumerated six different types of variations in the anterior belly: atavistic type, origin type, insertion type, mixed type, complex type and defect type. These types could also be subdivided into other groups, thus making this classification rather unclear.

In the present study, anatomical variations in the anterior belly of the digastric muscle in four individuals are described.

\section{MATERIAL AND METHOD}

The neck regions of ten formol-preserved cadavers of male adult individuals were dissected in the Department of Morphology, School of Medical Sciences, Santa Casa de São Paulo, between June 2004 and June 2006. Of these, four cadavers presented anatomical variations in the anterior belly of the digastric muscle. The digastric muscles that presented anatomical variations were photographed using a Sony Cybershot DSC-T1 camera with a Carl Zeiss Vario-Tessar lens, and its bellies were measured using a universal pachymeter.

\section{RESULTS}

Anatomical variations in the anterior bellies of the digastric muscle were observed in four individuals: two with unilateral variation and two with bilateral variation.

Case 1 presented right-side unilateral variation, with a triangular anterior belly inserted in the raphe of the mylohyoid muscle. The sides of this triangular belly measured $35 \mathrm{~mm}, 29 \mathrm{~mm}$ and $24 \mathrm{~mm}$ (Fig. 1).

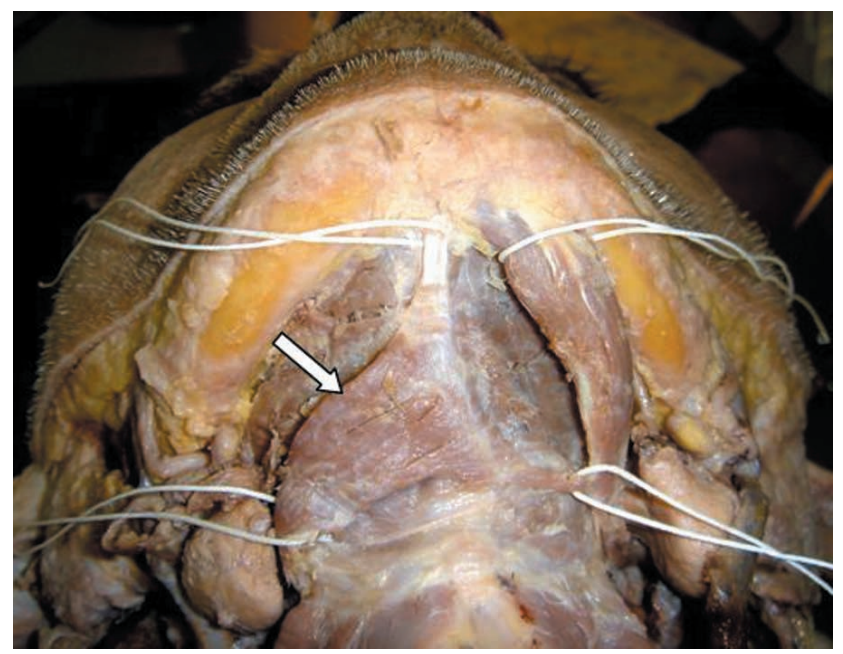

Fig. 1. Digastric muscle with anatomical variation in the right-side anterior belly, of triangular format (arrow).

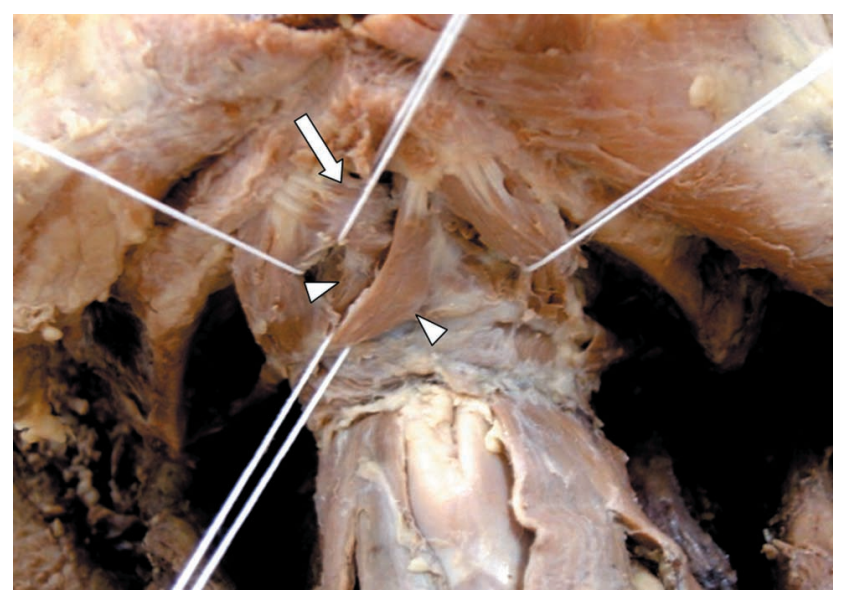

Fig. 2. Digastric muscle with bilateral variation, with two supernumerary bellies presenting attachment medially to the digastric fossa of the mandible and the contralateral intermediate tendon. The right-side supernumerary belly (arrow) divided the left-side supernumerary belly into anterior and posterior portions (arrow points), on crossing the median plane.

Case 2 presented bilateral variation, with the presence of two supernumerary bellies that originated medially to the digastric fossa of the mandible, with insertion in the 
contralateral intermediate tendon (Fig. 2). The right-side supernumerary belly (which measured $12 \mathrm{~mm}$ x $38 \mathrm{~mm}$ ) divided the left-side supernumerary belly (which measured $9 \mathrm{~mm} \times 39 \mathrm{~mm}$ ) into anterior and posterior portions when it crossed the median plane.

Case 3 presented bilateral variation with the presence of two supernumerary bellies, which also originated medially to the digastric fossa of the mandible, but with insertion in the raphe of the mylohyoid muscle, at a distance of $8 \mathrm{~mm}$ from the hyoid bone. The right-side supernumerary belly measured $15 \mathrm{~mm}$ x $5 \mathrm{~mm}$ and the left-side, $15 \mathrm{~mm}$ x $7 \mathrm{~mm}$ (Fig. 3).

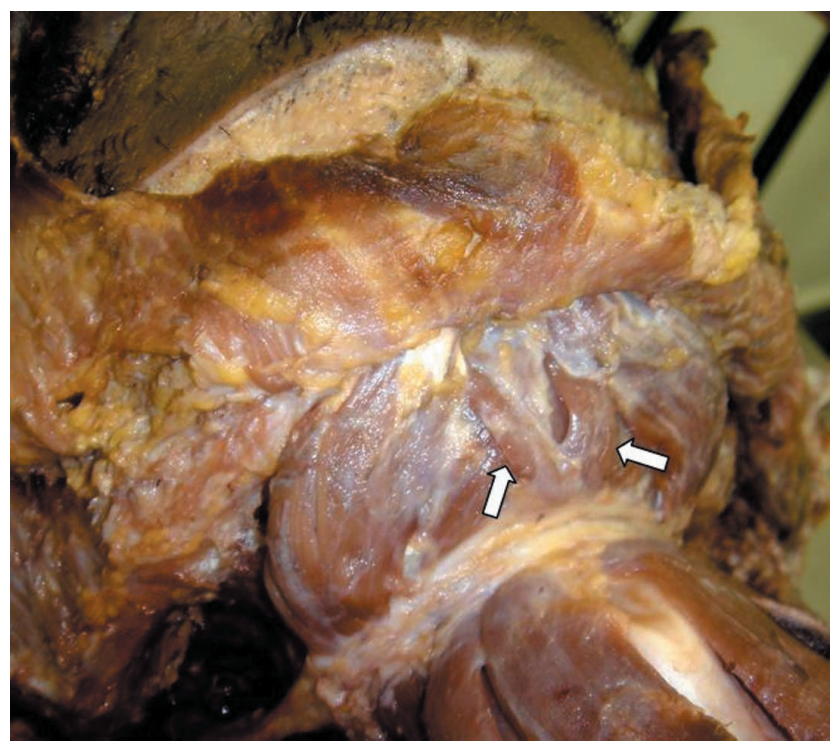

Fig. 3. Digastric muscle with bilateral variation, presenting two supernumerary bellies originating medially to the digastric fossa of the mandible (arrows) and insertion in the raphe of the mylohyoid muscle.

Case 4 presented right-side unilateral variation, with an anterior supernumerary belly inserted in the body of the hyoid bone, together with the insertion of the contralateral anterior belly. The supernumerary belly measured $45 \mathrm{~mm}$, $25 \mathrm{~mm}$ and $6 \mathrm{~mm}$, with a thickness of $5 \mathrm{~mm}$ (Fig. 4).

\section{DISCUSSION}

Despite the description in the literature that unilateral variations are more frequent (Sargon \& Celik, 1994; Peker et al., 2000), we observed the same proportions of unilateral and bilateral variations in this study. The muscle structures derived from the first pharyngeal arch, such as the anterior belly of the digastric muscle, originate from

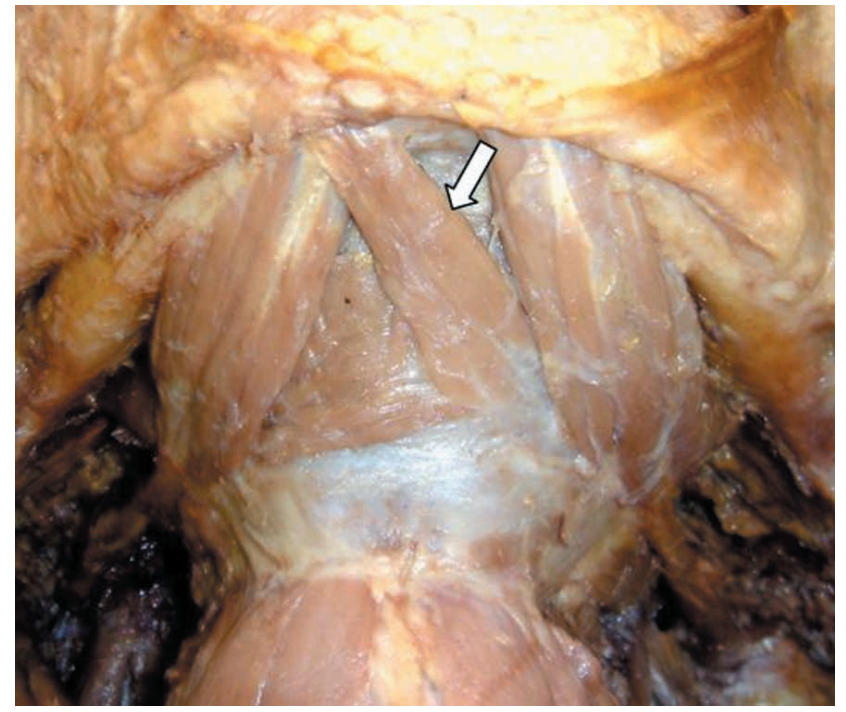

Fig. 4. Right-side unilateral variation, with supernumerary anterior belly (arrow) inserted in the body of the hyoid bone, together with the insertion of the contralateral anterior belly.

the original mesoderm of the arch (Moore \& Persaud). Thus, deficiency in the differentiation of this layer on one side may be responsible for unilateral variations, or deficiencies on both sides for bilateral variations.

Unilateral anatomical variations may present greater clinical importance, since in some cases they may be responsible for asymmetry in the anterior region of the neck or even in the movement of the floor of the mouth (Peker et al.) or the temporomandibular joint (Andreo et $a l ., 1997)$, and perhaps imbalance in the movement of the larynx. These types of asymmetry may lead to slight functional abnormalities or may even be confounded, in clinical examinations and in imaging examinations like ultrasound, tomography and magnetic resonance, with lymph nodes, benign cervical masses like thyroglossal cysts, or neoplasia (Turan-Ozdemir et al., 2004). Likewise, such conditions must be taken into consideration in surgical procedures in the neck region, especially in relation to submandibulectomy, since this muscle and its tendon are anatomical reference points during operations.

The anatomical variations observed in this study were limited to the anterior belly, as also described in other studies (Testut; Sargon \& Celik; Andreo et al.; Peker et al.; Bergman et al.; Fujimura et al.; Turan-Ozdemir et $a l$.). It is important to consider the occurrence of these variations in the digastric muscle when differentiating between cervical masses and during surgical procedures on the anterior region of the neck, especially in the submental and submandibular triangles. 
LIQUIDATO, B. M.; BARROS, M. D.; ALVES, A. L. \& PEREIRA, C. S. B. Estudio anatómica del músculo digástrico: Variaciones en el vientre anterior. Int. J. Morphol., 25(4):797-800, 2007.

RESUMEN: El músculo digástrico está formado por dos vientres musculares: uno anterior y otro posterior, unidos por un tendón intermedio. Está localizado en la región cervical anterior. El vientre anterior divide en dos la región entre el hueso hiodes y la mandíbula: lateralmente el trígono submandibular y medialmente el trígono submentoniano. Las variaciones anatómicas descritas en la literatura se refieren al vientre anterior y consisten en diferencias en la forma e inserción muscular. Este estudio de cohorte transversal tiene el objetivo de describir las variaciones anatómicas del vientre anterior del músculo digástrico. Diez regiones cervicales de cadáveres adultos masculinos fueron disecadas en el Departamento de Morfología entre junio de 2004 y junio de 2006. Los músculos digástricos que presentaron variaciones anatómicas fueron fotografiados usando una cámara Sony Cyber-shot DSC-T1 con un lente Carl Zeiss Vario-Tessar y sus vientres fueron medidos con un cáliper. Variaciones anatómicas en el vientre anterior del músculo digástrico se observaron en cuatro individuos. Los casos 1 y 4 presentaron variación unilateral derecha, con un vientre anterior anómalo. Los casos 2 y 3 presentaron variación bilateral, con presencia de dos vientres supernumerarios. Las variaciones anatómicas observadas en este estudio se refieren solamente el vientre anterior, el cual ha sido descrito previamente por otros autores. Es importante considerar la ocurrencia de estas variaciones en el músculo digástrico cuando se diferencian masas cervicales y durante los procedimientos quirúrgicos de la región anterior del cuello.

PALABRAS CLAVE: Músculos cervicales; Anatomía; Hueso hiodes.

\section{REFERENCES}

Andreo, J. C.; Navarro, J. A. C. \& Toledo, Filho, J. L. Anatomical study on the variations of the anterior belly of the digastric muscle. Rev. Chil. Anat., 15 (1):111-4, 1997.

Bergman, R.A.; Afifi, A. K. \& Miyauchi, R. Digastricus. In: Illustrated Encyclopedia of Human Anatomic Variation. Opus I: Muscular system; 2002. Available from: http:// www.anatomyatlases.org

Drake, R. L.; Vogl, W. \& Mitchell, A. W. M. Cabeça e pescoço. In: Drake, R. L.; Vogl, W. \& Mitchell, A. W. M. Gray's Anatomia para estudantes. $1^{\text {a }}$ ed. Rio de Janeiro, Elsevier, 2005. pp. 9057.

Fujimura, A.; Onodera, M, Feng, X. et al. Abnormal anterior belly of the digastric muscle: A proposal for the classification of abnormalities. Anat. Science Inter., 78:185-8, 2003.

Lockhart, R. D.; Hamilton, G. F. \& Fyfe, F. W. Músculos. In: Lockhart, R.D.; Hamilton, G. F. \& Fyfe, F. W. editores. Anatomia do corpo humano. $2^{\mathrm{a}}$ ed. Rio de Janeiro, Guanabara Koogan, 1983. pp. 156-7.

Moore, K. L. \& Persaud, T. V. N. Aparelho Faríngeo. In: Moore, K. L. \& Persaud, T. V. N. editores. Embriologia clínica. $7^{\mathrm{a}}$ ed. Rio de Janeiro, Editora Elsevier, 2004. pp. 226-35.

Peker, T.; Turgut, H. B. \& Anil, A. Bilateral anomaly bellies of digastric muscle. Surg. Radiol. Anat., 22:119-21, 2000.

Sargon, M. F. \& Celik, H. H. An abnormal digastric muscle with three bellies. Surg. Radiol. Anat., 16:215-6, 1994.

Snell, R. S. A cabeça e o pescoço. In: Snell, R.S. editor. Anatomia clínica para estudantes de Medicina. $5^{\mathrm{a}}$ ed. Rio de Janeiro, Guanabara Koogan, 1999. pp. 611-7.
Sociedade Brasileira deAnatomia. Terminologia Anatômica. Terminologia Anatômica Internacional. $1^{\mathrm{a}}$ ed. São Paulo, Manole, 2001. pp. 3-4

Testut, L. Traité D'Anatomie Humaine. Paris, Octave Doin, 1905. pp. 752-5.

Turan-Ozdemir, S.; Oygucu, I.H. \& Kafa, I. M. Bilateral abnormal anterior bellies of digastric muscles. Anat. Science Int., 79:957, 2004.

Yamada, S. Beobachfunger über der Venter anterior des Musculus digastricus mandibulae bei japanisher Erwachsenen und Foeter. Acta Anat. Nippon., 8:303-47, 1935.

Zlabek, K. Contribution a la connaissance des anomalies du ventre anterieur du digastrique de l'Homme. Arch. Anat. Histol. Embryol., 16:357-406, 1933.

Correspondence to:

Dr. Bianca Maria Liquidato

Departamento de Morfologia

Faculdade de Ciências Médicas de Santa Casa de São Paulo

R. Dr. Cesário Motta Jr., 61 - $11^{\circ}$ andar

CEP 01221-020,

São Paulo, SP,

BRAZIL

Email: bianca.liquidato@fcmscsp.edu.br

Received: 13-06-2007

Accepted: 26-08-2007 